\title{
EXPERIMENTAL INFECTION OF POMACEA AUSTRALIS (d'Orbiguy), REFRACTIVE FOR FASCIOLA HEPATICA (L.), RECEPTIVE TO ANGIOSTRONGYLUS CANTONENSIS (Chen)1
}

Pomacea australis, a large ampulariid fresh-water snail from Brazil, ${ }^{2}$ was imported by the Aquatic Weed Investigation Section, Crops Research Division, ARS, USDA, for the biological control of fresh-water weeds. Some live specimens were sent to us through the San Juan Laboratories of the U. S. Public Health Service to determine if this snail species serves as an intermediate host of Fasciola hepatica and Angiostrongylus cantonensis. ${ }^{4} F$. hepatica is a liver fluke which infests most ruminant species over the world, and occasionally man. $A$. cantonenis is a lungworm which occurs in rats on islands in the Pacific and in Southeast Asia. It too sometimes parasitizes man.

$P$. australis was exposed to $F$. hepatica infection in the following ways: 1, 200 one-day-old snails ( 2 to $2.5 \mathrm{~mm}$. in length) were placed in a large finger-bowl $(21 \mathrm{~cm}$.) which contained 4,000 liver fluke hatching eggs in $200 \mathrm{ml}$. of distilled water; 2, ten 2-month-old snails (11-12 mm.) were put in each of 5 large finger-bowls each containing 2,000 eggs in $200 \mathrm{ml}$. of distilled water; 3 , ten 6-month-old snails $(30-40 \mathrm{~mm}$.) were held in each of 5 large finger-bowls each containing 2,000 eggs in $200 \mathrm{ml}$. of distilled water. All exposures lasted for 4 hours at room temperature of $29^{\circ}$ to $31^{\circ} \mathrm{C}$.

The snails were held in plastic aquaria of 12-gallon capacity, half-filled with previously aerated tap-water and provided with air pumps. Fresh malanga leaves (Caladium sp.) were fed 2 to 3 times a week.

Half the snails of each age group were crushed gently with a small hammer 3 weeks post-exposure and their "livers" separated from other tissues and shell fragments. The "livers" then were pressed between two slides and examined under the microscope for $F$. hepatica rediae. The remainder of the snails were examined similarly 6 weeks post-exposure.

No rediae were observed in any of the snails of the three age-groups

- 1.Thanks are expressed to Dr. F. F. Ferguson, U. S. Public Health Service, San Juan, for advice and interest in the work; Dr. J. D. Rivera Anaya, Agricultural Experiment Station, Mayagüez Campus, University of Puerto Rico, Río Piedras, P.R., for numerous suggestions and assistance; and Dr. J. E. Alicata, College of Tropical Agriculture, University of Hawaii, Oahu, Hawaii, for a supply of A. cantonensis.

2 de Olivei, S. L., About control of Anacharias densa by Tilapia melanopleura and Pomacea caniculata, Agronomí, 18 (5): 117-27, 1960.

${ }^{3}$ Maldonado, J. F., Helmintiases del Hombre en América, Editorial CientíficoMédico, Barcelona-Marid-Lisboa, 359-372, 1965.

- de Lebn, D. D., No Angiostrongylus cantonensis (Nematoda: Metastrongylidae) observed in 108 rats in San Juan, P.R., J. Agr. Univ. P.R. 48 (4): 353-54, 1964. 
exposed to $F$. hepatica miracidia, an indication that the snail $P$. australis likely is not susceptible to liverfluke infection. This observation supports the statement of C. A. Wrights "that the snails serving as intermediate host to this parasite ( $F$. hepatica) throughout the world all belong to a closely-related group of amphibious members of this genus (Lymnaea)."

$P$. australis was exposed to $A$. cantonensis infection in the following ways: 1,100 one-day-old snails were placed in a small finger-bowl $(10.5 \mathrm{~cm}$.), with a filter paper over the bottom, which contained 1,000 first-stage larvae in $100 \mathrm{ml}$. distilled water; 2, ten 2-month-old snails were placed in each of 5 large finger-bowls, with a filter paper over the bottom, each containing 500 larvae in $400 \mathrm{ml}$. of distilled water; 3, ten 6-month-old snails were placed in each of five large finger-bowls, with a filter paper over the bottom, each containing 500 larvae in $400 \mathrm{ml}$. of distilled water. All exposures were for 7 hours at room temperature of $29^{\circ}$ to $31^{\circ} \mathrm{C}$. The snails were maintained as described above.

At 4 weeks postexposure all the snails in the three-age groups were crushed and their "foot" isolated. Three thin sections, about $10 \mathrm{~mm}$. long, were made from each "foot" and examined between two glass slides under the microscope.

The day-old and 2-month-old snails became infected with the lungworm, A. cantonensis. Between one and three third-stage, infective, larvae were observed in 87 percent of the day-old snails and one to two larvae in 9 percent of the 2-month-old snails. No larvae were observed in the 6-monthold snails. To confirm this observation, parts of the "foot" and soft tissues of the 6-month-old snails were digested artificially with 1-percent pepsin and hydrochloric acid solution. Such preparations did not show any infective larva.

The third-stage larvae, recovered by artificial digestion from the "foot" and soft tissues of day-old snails, developed into young adult $A$. cantonensis 30 days after being given to white rats.

Delfin de Lebn-Dancel

Department of Animal Husbandry

- Taylor, E. L., Fascioliasis and the Liver-Fluke, F. A. O. Agricultural Studies No. 64-9, 1964 . 